\title{
Inhibitory effects of zinc hyaluronate on synoviocyte growth and matrix metalloproteinase- 9 activity
}

This article was published in the following Dove Press journal:

Journal of Inflammation Research

16 November 2009

Number of times this article has been viewed

\author{
Seiji Saito \\ Keisei Maekawa \\ Shigeru Kotake \\ Institute of Rheumatology, \\ Tokyo Women's Medical \\ University, Tokyo, Japan
}

Correspondence: Seiji Saito Institute of Rheumatology, Tokyo Women's Medical University, 10-22

Kawada-cho, Shinjuku-ku, Tokyo

162-0054, Japan

Tel $+8|35269| 725$

Fax +8I 35269 I726

Email stcmsait@ior.twmu.ac.jp

\begin{abstract}
Sodium hyaluronate (Na-HA) is a therapeutic agent used for treating knee arthritis. However, it has been unsuccessfully used in the treatment of knee effusions. Joint effusion results from synovial activation and growth, leading to an increase in the production of matrix metalloproteinases (MMPs), especially MMP-9. This study aimed to determine whether the newly developed zinc hyaluronate ( $\mathrm{Zn}-\mathrm{HA})$ is more effective than Na-HA in inhibiting the growth of synoviocytes or production and activity of MMPs in rheumatoid synoviocytes. Our results showed that Zn-HA inhibited synoviocyte growth, MMP-9 protein production, and MMP-9 mRNA expression, whereas Na-HA exerted only a slight inhibitory effect on these parameters. Moreover, Zn-HA induced synoviocyte apoptosis, whereas Na-HA did not. These results suggest that $\mathrm{Zn}$-HA retards synoviocyte growth by inducing apoptosis following a decrease in the production of MMP-9 and mRNA. Therefore, it is suggested that Zn-HA can suppress arthritis more efficiently than Na-HA.
\end{abstract}

Keywords: synoviocyte, apoptosis, sodium hyaluronate, zinc hyaluronate, rheumatoid arthritis, MMP-9

\section{Introduction}

Viscosupplementation with sodium hyaluronate (Na-HA) is known to provide relief from knee pain. ${ }^{1}$ However, a wide range of inter- and intra-trial variations in the therapeutic efficacy of Na-HA have been reported. One explanation for these variations is that the viscosupplement becomes diluted because of the large amounts of synovial fluid present in effusions.

Effusion is caused by synovial hypertrophy due to the development of synovitis in rheumatoid arthritis (RA), secondary synovitis in osteoarthritis (OA), and the production of excessive hyaluronate (HA), which is induced by interleukin-1 (IL-1) alpha and beta and tumor necrosis factor (TNF)-alpha. ${ }^{2}$ Increased synoviocyte proliferation and decreased synoviocyte apoptosis contribute to synovial hypertrophy.

Matrix metalloproteinases (MMPs) are abundantly found in the synovial effusion seen in RA and OA cases. ${ }^{3}$ MMPs, especially MMP-9, which is inducible by inflammatory cytokines-stimulated synoviocytes, ${ }^{4}$ are proteolytic enzymes responsible for articular destruction. ${ }^{5}$ Therefore, an ideal therapeutic agent for effusions is one that inhibits synoviocyte proliferation, accelerates synoviocyte apoptosis, and prevents MMP production.

Certain physical and biological characteristics of purified HA, such as short residence time in tissues, limit its application as a therapeutic agent. Thus, several 
attempts have been made to modify the molecular structure of HA in order to obtain a more stable form. Two approaches, namely, the formation of counterion-HA complexes and cross-linking, are used to construct a modified, stable form of HA. ${ }^{6}$ Because of the presence of free carboxyl groups on the glucuronide (GlcU) units, HA has a polyanionic characteristic that allows complex formation with cations. Several counterion-HA complexes have been prepared to investigate the potential effects of various cations. ${ }^{7-11}$ Balogh and colleagues investigated the degradation and antioxidant activities of counterion-HA complexes and reported that these complexes are therapeutically more effective than Na-HA. Among the counterion-HA complexes, zinc hyaluronate (Zn-HA) exerts a positive effect against the antioxidant activity, unlike Na-HA. ${ }^{6}$

While most heavy metals are toxic, Zinc is safe for internal use. ${ }^{12}$ Zinc is also known to play a regulatory role in the immune system; it can have anti-inflammatory effects, apparently as a consequence of direct interaction with cytokines secreted by monocytes. ${ }^{13}$ Zinc protects against lipopolysaccharide (LPS) hepatotoxicity by inhibiting TNF production. The inhibitory effect of zinc on LPS-induced TNF production results from the modulation of the oxidative stress-sensitive nuclear factor- $\kappa \mathrm{B}$ pathway. ${ }^{14}$

Recently, high-molecular-weight Na-HA was reported to suppress the proliferation of rabbit synovial cells $;^{15}$ according to a report on the estimation of the biological activity of $\mathrm{Na}-\mathrm{HA}$ on apoptosis of RA synovial cells has almost no effect on apoptotic change. ${ }^{16}$ Thus, it is not known whether Na-HA or Zn-HA could possibly induce apoptosis in synovial cells.

In this preclinical study, we investigated whether the newly developed Zn-HA suppresses the growth of or increases apoptosis in fibroblast-like synoviocytes. We also investigated the effects of Zn-HA on MMP activity in order to confirm the efficacy of $\mathrm{Zn}-\mathrm{HA}$ as a therapeutic agent for knee effusions in patients with RA.

\section{Patients and methods}

\section{Patients selection}

By performing prosthetic arthroplasty or arthroscopy, synovial tissues were obtained from patients with $\mathrm{RA}(\mathrm{n}=5$; male: female $[\mathrm{M}: \mathrm{F}]=1: 4$; age, $65.5 \pm 10.6$ years $)$, with OA $(\mathrm{n}=6$; $\mathrm{M}: \mathrm{F}=0: 6$; age, $73.4 \pm 8.9$ years $)$, and control patients $(\mathrm{n}=6$; $\mathrm{M}: \mathrm{F}=5: 1$; age, $25.6 \pm 6.7$ years) with a traumatic knee (TA) caused by anterior cruciate ligament ruptures. In keeping with the ethical requirements mandated by our university, written informed consent was obtained from all patients prior to the commencement of the study. The patients with RA and OA fulfilled the respective American College of Rheumatology criteria for their diagnoses. ${ }^{17,18}$ The synovial tissues were digested with $0.1 \%$ trypsin (Wako Pure Chemicals, Osaka, Japan) for 30 minutes at $37^{\circ} \mathrm{C}$. The cells were then digested with $0.1 \%$ collagenase (Wako Pure Chemicals) for two hours at $37{ }^{\circ} \mathrm{C}$. The cells were maintained in $5 \% \mathrm{CO}_{2}$ atmosphere at $37{ }^{\circ} \mathrm{C}$ for 48 hours and then used for further analyses. The synoviocytes were serially passaged and used at passages $3-5$.

\section{Test agents}

The following test agents were used: $\mathrm{Zn}-\mathrm{HA}$ (lot no. A65242; Gedeon Richter Ltd., Budapest, Hungary), Na-HA (lot no. KK4001; Kewpie, Tokyo, Japan), and $\mathrm{ZnCl}_{2}$ (lot no. ESH1413; Wako Pure Chemicals). The specific gravity of the $\mathrm{Zn}-\mathrm{HA}$ solution was 1.0134; HA content, 99\% (105.0\% when converted to Na-HA); and $\mathrm{Zn}$ content, $1.07 \mathrm{mg} / \mathrm{mL}$. Thus, the weight ratio of HA (when converted to Na-HA) and $\mathrm{Zn}$ (when converted to $\mathrm{ZnCl}_{2}$ ) in $\mathrm{Zn}-\mathrm{HA}$ was set at 10:1 (Na-HA: $\mathrm{ZnCl}_{2}$ ) in subsequent experiments. When the $\mathrm{Zn}-\mathrm{HA}$ concentration was $100 \mu \mathrm{g} / \mathrm{mL}$, the $\mathrm{Na}-\mathrm{HA}$ and $\mathrm{ZnCl}_{2}$ concentrations were calculated to be $100 \mu \mathrm{g} / \mathrm{mL}$ and $10 \mu \mathrm{g} / \mathrm{mL}$, respectively. The maximal doses for $\mathrm{Zn}-\mathrm{HA}$ and $\mathrm{Na}-\mathrm{HA}$ were $300 \mu \mathrm{g} / \mathrm{mL}$ and for $\mathrm{ZnCl}_{2}, 30 \mu \mathrm{g} / \mathrm{mL}$. The molecular weight of $\mathrm{Na}-\mathrm{HA}$ is approximately $1,000,000$.

\section{Determination of the proliferative capacity of synoviocytes}

Synoviocytes were inoculated into 96-well microplates $\left(1 \times 10^{4}\right.$ cells $\left./ \mathrm{cm}^{2}\right)$, and the test agents $(\mathrm{Zn}-\mathrm{HA}, \mathrm{Na}-\mathrm{HA}$, and $\mathrm{ZnCl}_{2}$ ) were added to these plates. Following incubation, the proliferative capacity of the cells was determined using the tetrazolium-based colorimetric 3-[4, 5-dimethylthiazol2-yl]-2, 5-diphenyltetrazolium bromide (MTT) assay at a wavelength of $540 \mathrm{~nm} .{ }^{19}$

\section{Evaluation of MMP-I, MMP-2, MMP-3, MMP-9,TIMP-I, and TIMP-2 production}

The test agents were added to the synoviocytes $\left(1 \times 10^{4}\right.$ cells $/ \mathrm{cm}^{2}$ ) obtained from patients with RA, OA, or TA. MMP-1, MMP-2, MMP-3, MMP-9, TIMP-1, and TIMP-2 were detected with an enzyme immunoassay by using a onestep sandwich enzyme immunoassay kit (Fuji Chemical Industries, Toyama, Japan). In order to express the results as the ratios of the amount of enzyme produced to the number of cells in the culture supernatant, the enzyme concentration 
was divided by the absorption of the synoviocytes, as determined by the MTT assay. The control value was set at $100 \%$. The data for the groups treated with the test agents are expressed as relative values.

\section{Preparation of the synoviocytes obtained from RA patients for measuring MMP-9 enzyme concentration and MMP-9 mRNA expression levels}

The synoviocytes $\left(6 \times 10^{5}\right.$ cells $\left./ \mathrm{cm}^{2}\right)$ obtained from RA patients were incubated with phorbol 12-myristate 13-acetate (PMA; concentration, $100 \mathrm{ng} / \mathrm{mL}$; Sigma-Aldrich Japan, Tokyo, Japan) and a test agent ( $\mathrm{Zn}-\mathrm{HA}, \mathrm{Na}-\mathrm{HA}$, or $\mathrm{ZnCl}_{2}$ ), and the cells were further cultured for 48 hours. Viable cells were counted using the MTT assay.

\section{Analysis of MMP-9 enzyme by gelatin zymography and MMP-9 mRNA expression by reverse transcriptase- polymerase chain reaction}

For estimating the MMP-9 activity, the culture supernatant was analyzed by gelatin zymography. Samples were resolved using sodium dodecyl sulfate-polyacrylamide gel electrophoresis (SDS-PAGE) on $0.1 \%$ gelatin gels containing $12.5 \%$ SDS, followed by an overnight enzymatic reaction at $37^{\circ} \mathrm{C}$. The protein component was stained with Coomassie brilliant blue at ambient temperature for 30 minures. The unstained bands were semiquantified using the NIH Image software. proMMP-9 (92 kDa) and proMMP-2 (72 kDa) were used as positive controls.

To prepare the cDNA (RETROscript kit; Ambion, Austin, TX, USA) for reverse transcriptase-polymerase chain reaction (RT-PCR), total RNA was extracted from the synoviocytes, with or without prior PMA exposure (RNAqueous kit; Ambion/Applied Biosystems, Austin, TX, USA). For polymerase chain reaction (PCR), glyceraldehyde-3-phosphate dehydrogenase (GADPH) was used as the internal control, and the primer pairs used were as follows:

1. For human MMP-9 (GenBank accession no. J05070):

a. 5'-CCT GCC ACT TCC CCT TCA TCT-3' (sense)

b. 5'-CCG CCA CGA GGA ACA AAC TG-3' (antisense)

2. For human GAPDH (GenBank accession no. M33197):

a. 5'-ACC ACA GTC CAT GCC ATC AC-3' (sense)

b. 5'-TCC ACC ACC CTG TTG CTG TA-3' (antisense).

The PCR protocol comprised of 32 cycles of denaturation at $94{ }^{\circ} \mathrm{C}$ for 30 seconds, annealing at $60{ }^{\circ} \mathrm{C}$ for 40 seconds, and a final extension at $72{ }^{\circ} \mathrm{C}$ for 80 seconds. MMP-9 mRNA expression was semiquantitatively adjusted by comparing it with GAPDH mRNA expression.

\section{Evaluation of Zn-HA-induced synoviocyte apoptosis}

RA synoviocytes $\left(1 \times 10^{4}\right.$ cells $\left./ \mathrm{cm}^{2}\right)$ were cultured, and the test agents were added to the cells. These cultures were incubated for an additional five days. In accordance with the protocol, apoptosis in the RA synoviocytes was examined by staining, using the terminal deoxynucleotidyl transferase (TdT)-mediated dUTP-biotin nick end labeling (TUNEL) method (Apoptosis screening kit and Mebstain apoptosis TUNEL kit direct from Wako, Tokyo, Japan, and MBL, Tokyo, Japan, respectively). The samples were subsequently analyzed using an apoptosis enzyme-linked immunosorbent assay (ELISA; ApoStrand ELISA apoptosis detection kit; Biomol International LP, Plymouth Meeting, PA, USA).

\section{Statistical analysis}

Data were analyzed using the Kruskal-Wallis one-way analysis of variance (ANOVA) with masking. Multiple comparisons were performed using Dunnett's or Tukey's methods. The suppression of synoviocyte proliferation was determined by simple regression analysis. All statistical calculations were performed using the software programs Statistical Package for the Social Sciences (v 11.0J; SPSS Japan Inc., Tokyo, Japan) and JMP 6.02 (SAS Inc., Tokyo, Japan). The significance level was set at $<5 \%$.

\section{Results}

\section{Effect of $\mathrm{Zn}-\mathrm{HA}$ on synoviocyte proliferation}

$\mathrm{Zn}-\mathrm{HA}$ doses of $>150 \mu \mathrm{g} / \mathrm{mL}$ significantly suppressed the proliferation of the synoviocytes obtained from the RA (Figure 1A), OA (Figure 1B), and TA patients (Figure 1C). $\mathrm{ZnCl}_{2}$ doses of $>20 \mu \mathrm{g} / \mathrm{mL}$ exerted a similar effect; however, in order to suppress synoviocyte proliferation to the same extent as $\mathrm{Zn}-\mathrm{HA}$, higher concentrations of $\mathrm{ZnCl}_{2}$ were required. The inhibition of synoviocyte proliferation reached a plateau at the $\mathrm{Zn}-\mathrm{HA}$ dose of $250 \mu \mathrm{g} / \mathrm{mL}$. On the other hand, although the inhibition of synoviocyte proliferation did not reach a plateau, a $\mathrm{ZnCl}_{2}$ dose of $30 \mu \mathrm{g} / \mathrm{mL}$ suppressed cell proliferation. In contrast, Na-HA did not significantly suppress synoviocyte proliferation even at a maximal dose of $300 \mu \mathrm{g} / \mathrm{mL}$. 


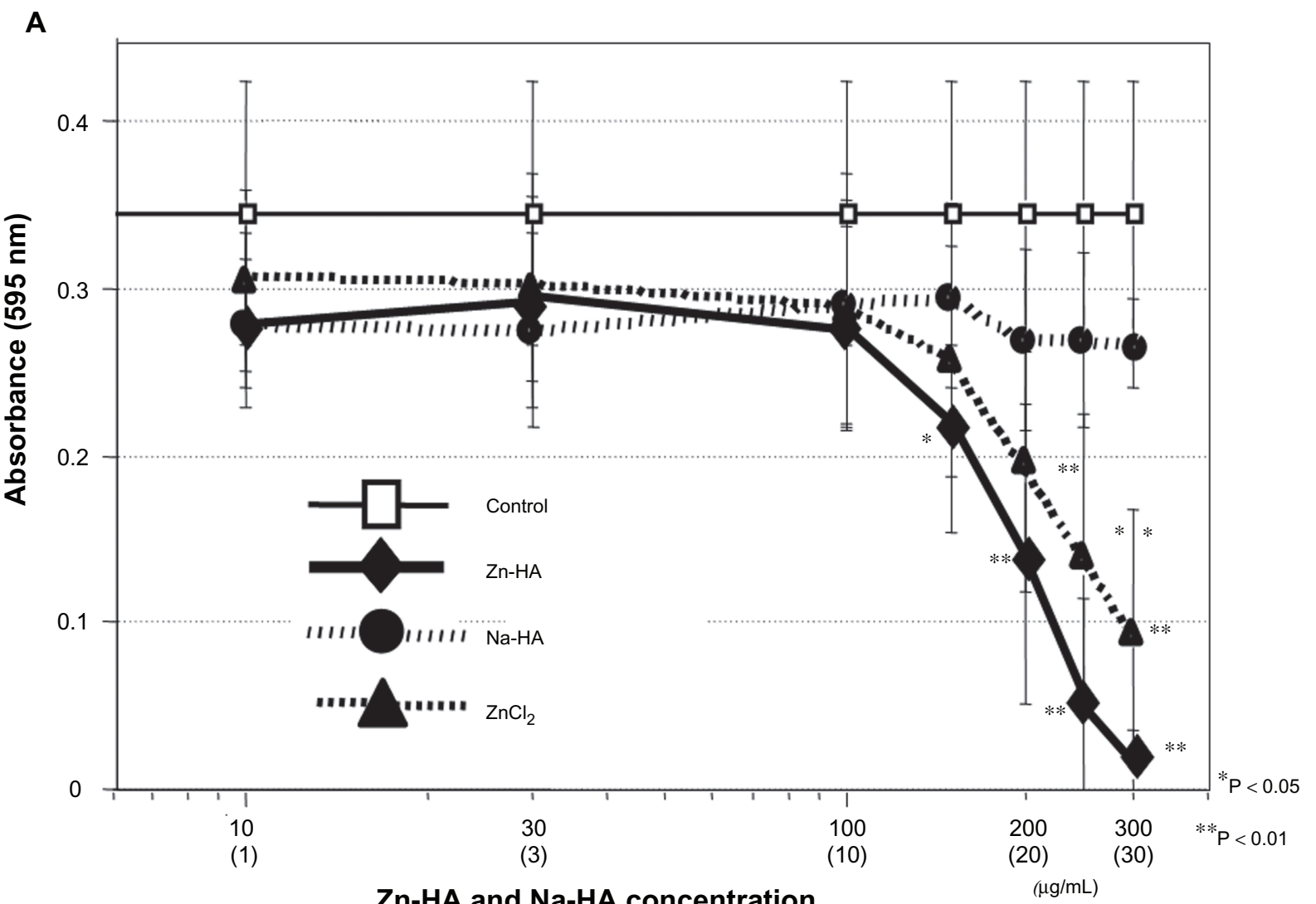

$\mathrm{Zn}-\mathrm{HA}$ and Na-HA concentration

( $\mathrm{Zn}$ concentration of $\mathrm{ZnCl}_{2}$ )

B

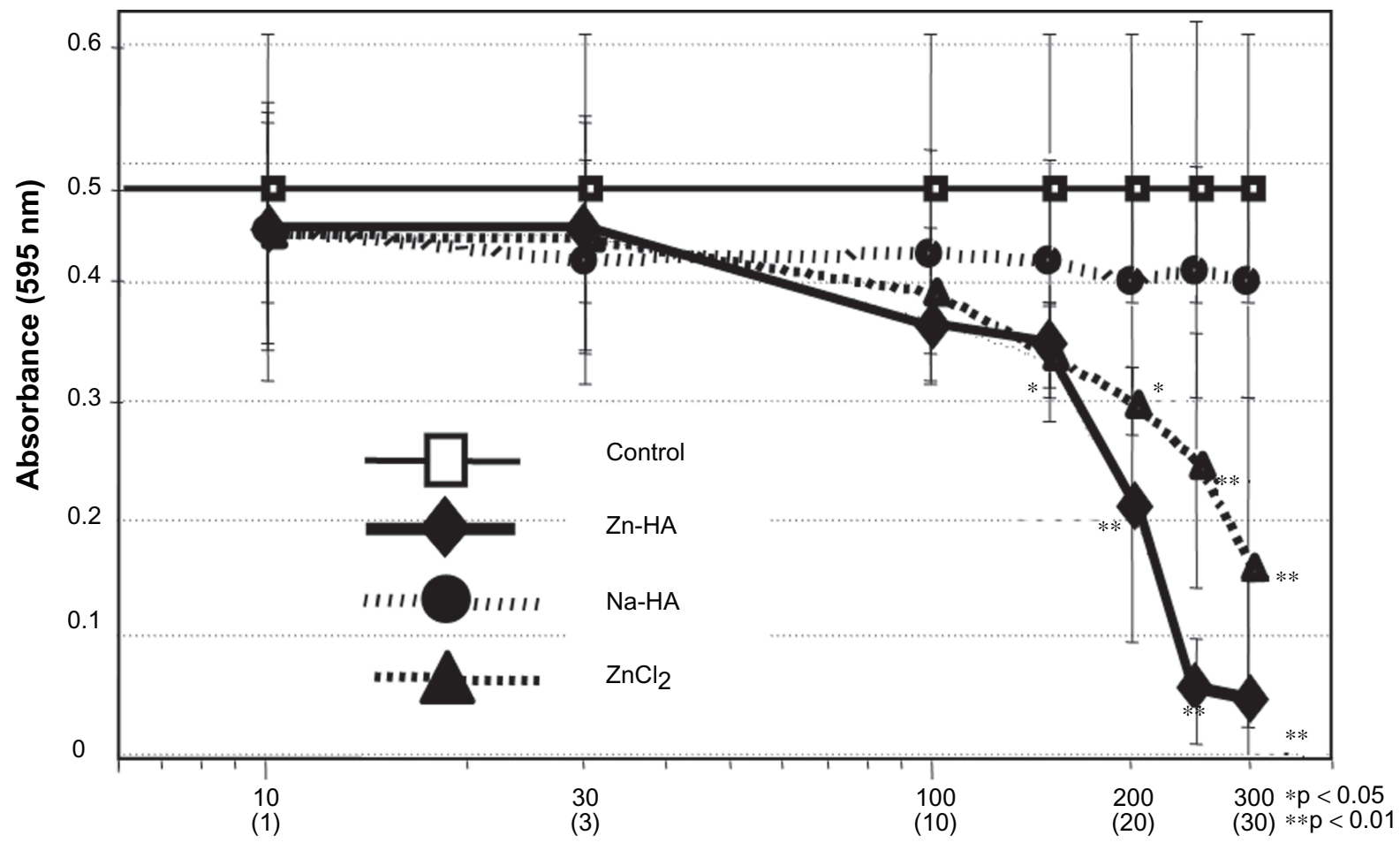

$\mathrm{Zn}-\mathrm{HA}$ and $\mathrm{Na}-\mathrm{HA}$ concentration

( $\mathrm{Zn}$ concentration of $\mathrm{ZnCl}_{2}$ ) 
C

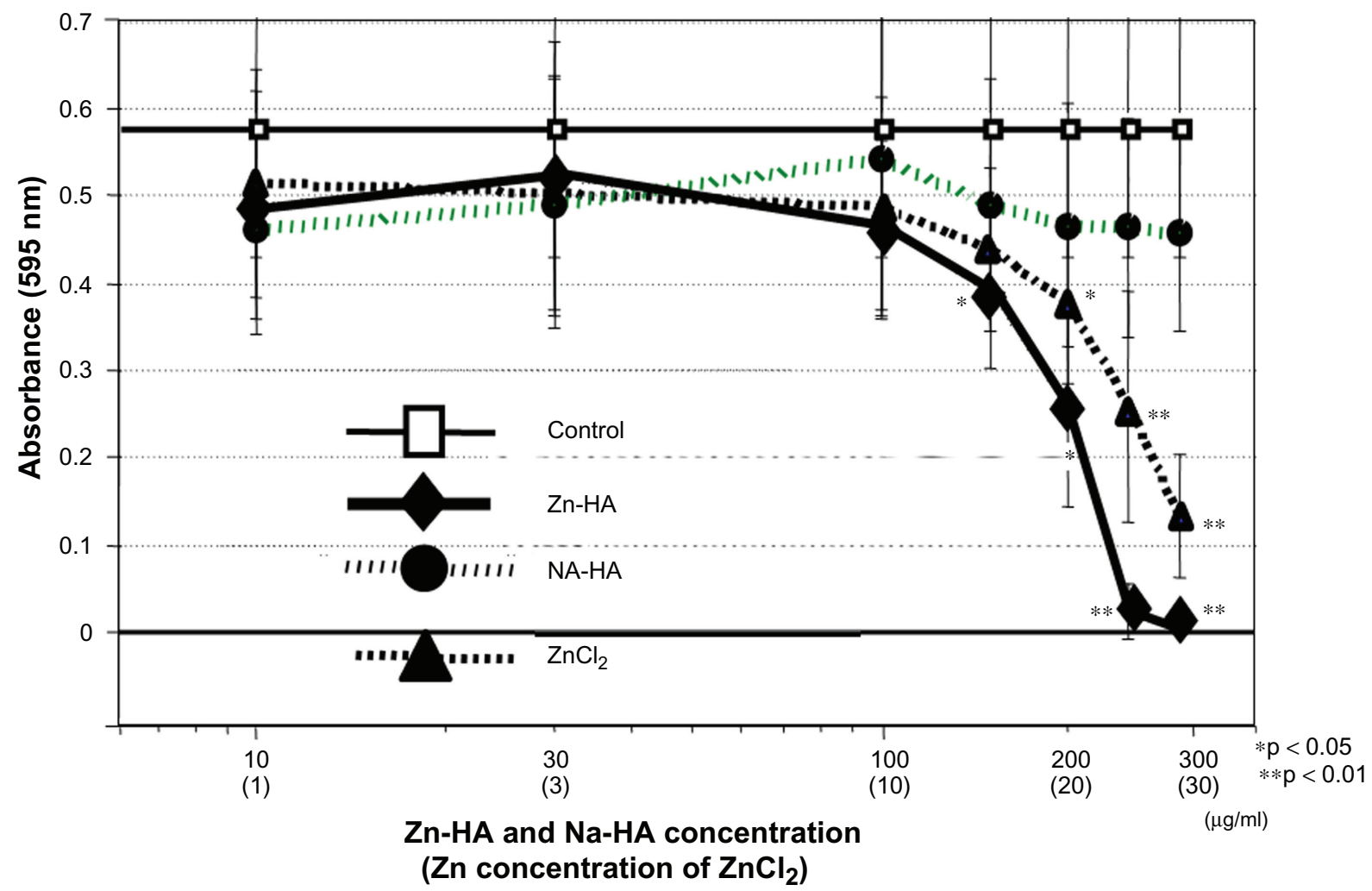

Figure I Effects of $\mathrm{Zn}-\mathrm{HA}, \mathrm{Na}-\mathrm{HA}$, and $\mathrm{ZnCl}_{2}$ on the growth of synoviocytes obtained from the RA A), OA B), and TA C) patients after the addition of the test agents. Abbreviations: RA, rheumatoid arthritis; OA, osteoarthritis; TA, traumatic knee; $\mathrm{Zn}-\mathrm{HA}$, zinc hyaluronate; $\mathrm{Na}-\mathrm{HA}$, sodium hyaluronate.

\section{Estimation of the therapeutic concentration of $\mathrm{Zn}-\mathrm{HA}$}

Based on the slope of the simple regression lines of the plotted growth curves, we estimated the therapeutic concentrations of $\mathrm{Zn}-\mathrm{HA}$ or $\mathrm{ZnCl}_{2}$ required to reduce the proliferative capacity of the RA synoviocytes to the same extent as that of the TA synoviocytes. Between 100 and $250 \mu \mathrm{g} / \mathrm{mL} \mathrm{Zn}-\mathrm{HA}$ and between 10 and $30 \mu \mathrm{g} / \mathrm{mL} \mathrm{ZnCl}_{2}$, the negative regression equations were $\mathrm{Y}=-1.26 \times 10^{-4} \mathrm{X}+$ $0.003(r=0.995)$ and $Y=-8.26 \times 10^{-4} X+0.003(r=0.993)$, respectively (Figure $2 \mathrm{~A}$ ). From these equations, the therapeutic concentration of $\mathrm{X}$ was calculated using $\mathrm{Y}=0.0178$ as derived from the slope of the proliferation curve of TA synoviocytes. The doses of $\mathrm{Zn}-\mathrm{HA}$ and $\mathrm{ZnCl}_{2}$ required to suppress the proliferation of RA synoviocytes to the same extent as that of TA synoviocytes were calculated to be $128.97 \mu \mathrm{g} / \mathrm{mL}$ and $14.96 \mu \mathrm{g} / \mathrm{mL}$, respectively (Figure 2B).

\section{Production of MMP and TIMP proteins obtained from RA, OA, and TA patients}

We performed an enzyme immunoassay to analyze the MMPs and TIMPs released by untreated synoviocytes into a culture medium. High concentrations of MMP-1, MMP-3, and MMP-9 were produced by RA synoviocytes. The synoviocytes obtained from OA patients and control patients with TA produced MMPs in comparable concentrations. The concentrations of MMP-2 and TIMP-1 produced by synoviocytes obtained from the patients with RA and OA were similar to that produced by TA synoviocytes. TIMP-2 production was not detected in any of the cells (Figure 3).

\section{Effect of $\mathrm{Zn}-\mathrm{HA}$ on MMP protein production in treated synoviocytes obtained from RA, OA, and TA patients}

Synoviocytes were treated with test agents during culture. The production of MMPs by the treated cells was measured using an enzyme immunoassay. Zn-HA and Na-HA were used at concentrations of 100,150 , and $200 \mu \mathrm{g} / \mathrm{mL}$ while $\mathrm{ZnCl}_{2}$ was used at 10,15 , and $20 \mu \mathrm{g} / \mathrm{mL}$ concentrations.

\section{Observations in RA patients}

Both $\mathrm{Zn}-\mathrm{HA}$ and $\mathrm{ZnCl}_{2}$ suppressed MMP-9 production in RA synoviocytes. MMP-9 concentration was completely blocked and showed below the detection limit for the specified 
A

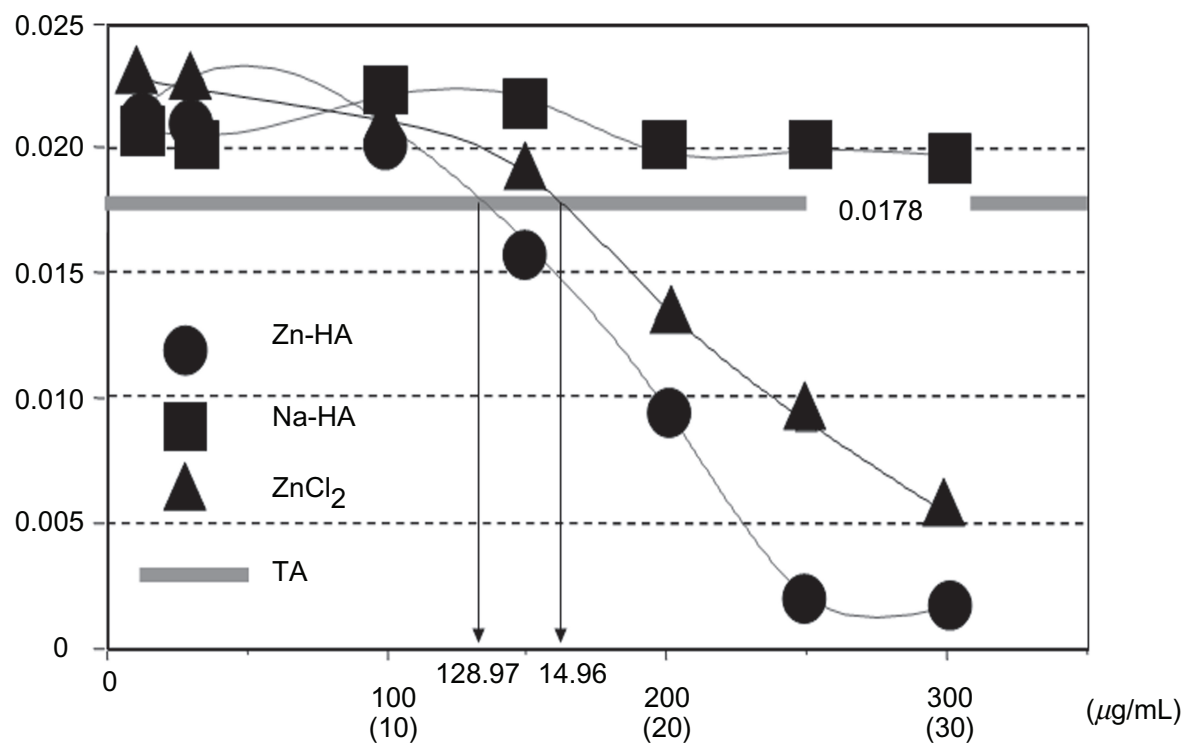

Zn-HA, Na-HA cocncentration

B ( $\mathrm{ZnCl}_{2}$ concentration)

\begin{tabular}{|c|ccc|}
\hline Drugs & Concentration*1 & Regression line (correlation coefficient) & TC level *2 \\
\hline $\mathrm{Zn}-\mathrm{HA}$ & $100-250$ & $\mathrm{Y}=-1.26 \times 10^{-4} \times+0.003(\mathrm{r}=0.995)$ & 128.97 \\
\hline $\mathrm{ZnCl} 2$ & $10-30$ & $\mathrm{Y}=-8.26 \times 10^{-4} \times+0.003(\mathrm{r}=0.993)$ & 14.96 \\
\hline
\end{tabular}

Figure 2 A) Estimated therapeutic concentrations of $\mathrm{Zn}-\mathrm{HA}$, calculated on the basis of the slope of the growth regression line of the synoviocytes obtained from the RA patients. B) $\mathrm{Zn}-\mathrm{HA}$ and $\mathrm{ZnCl}_{2}$ resulted in the following negative regression linear equations at $100-250 \mu \mathrm{g} / \mathrm{mL}$ and $10-30 \mu \mathrm{g} / \mathrm{mL}$, respectively: $\mathrm{Y}=-1.26 \times 10^{-4} \mathrm{X}+0.034$ $(r=0.995)$ and $Y=-8.26 \times 10^{-4} X+0.030(r=0.993)$. Therapeutic concentration $(X)$, which gives the slope $(Y=0.0178)$ of the growth regression line of the synoviocytes obtained from the TA patients, was calculated from these equations. $\mathrm{Zn}-\mathrm{HA}(128.97 \mu \mathrm{g} / \mathrm{mL})$ and $\mathrm{ZnCl}_{2}(1 / 4.96 \mu \mathrm{g} / \mathrm{mL})$ inhibited the growth of synoviocytes obtained from the RA patients (compared with the growth of those obtained from the TA patients).

Notes:*I Concentration, $\mu \mathrm{g} / \mathrm{mL}$. *2 TC level (therapeutic concentration level). $X$ is the therapeutic concentration required to reduce the slope of the growth regression line of the synoviocytes obtained from the RA patients to that of the synoviocytes obtained from the TA patients $(Y=0.0178)$.

Abbreviations: RA, rheumatoid arthritis; OA, osteoarthritis; TA, traumatic knee; Zn-HA, zinc hyaluronate; Na-HA, sodium hyaluronate.

concentrations of Zn-HA. Further, MMP-9 was inhibited to approximately $50 \%$ by $10 \mu \mathrm{g} / \mathrm{mL} \mathrm{ZnCl}_{2}(P<0.05)$ and completely blocked by 15 and $20 \mu \mathrm{g} / \mathrm{mL} \mathrm{ZnCl}{ }_{2}$. In contrast, Na-HA did not inhibit MMP-9 production. MMP-1, MMP-2 and MMP-3 were not affected by treatment with Zn-HA, $\mathrm{ZnCl}_{2}$, or Na-HA (Figure 4A). As compared to the concentration of TIMP-1 released into the control medium, its concentration tended to increase with increasing concentrations of $\mathrm{Zn}-\mathrm{HA}$, but not with increasing concentrations of $\mathrm{ZnCl}_{2}$ or Na-HA (data not shown). Regardless of the test agent used, the synoviocytes obtained from the patients with RA did not produce TIMP-2 (data not shown).

\section{Observations in OA patients}

MMP-9 production was detected in TA synoviocytes as control, but MMP-9 concentrations remained below the detection limit after treatment with all the specified concentrations of $\mathrm{Zn}-\mathrm{HA}$ and $\mathrm{ZnCl}_{2}$; this was not the case after Na-HA treatment. Treatment with $200 \mu \mathrm{g} / \mathrm{mL} \mathrm{Zn}-\mathrm{HA}$ inhibited MMP-1 and MMP-2 production by OA synoviocytes to approximately $25 \%$ (mean) of the corresponding levels in TA synoviocytes, in a concentration-dependent manner $(P<0.05)$. MMP-3 production with $\mathrm{Zn}-\mathrm{HA}$ was decreased in a concentration-dependent manner but not statistically significant. MMP-3 produced after treatment with specified concentrations of $\mathrm{Na}-\mathrm{HA}$ and $\mathrm{ZnCl}_{2}$ were comparable to the concentrations of these proteins released into the TA control medium (Figure 4B). Treatment with $200 \mu \mathrm{g} / \mathrm{mL}$ Zn-HA tended to decrease the levels of TIMP-1 in a concentration-dependent manner, to approximately $50 \%$ of the levels in the control medium (data not shown). The concentration of TIMP-2 released into the culture medium was below the detection limit, regardless of the test agent used (data not shown). 

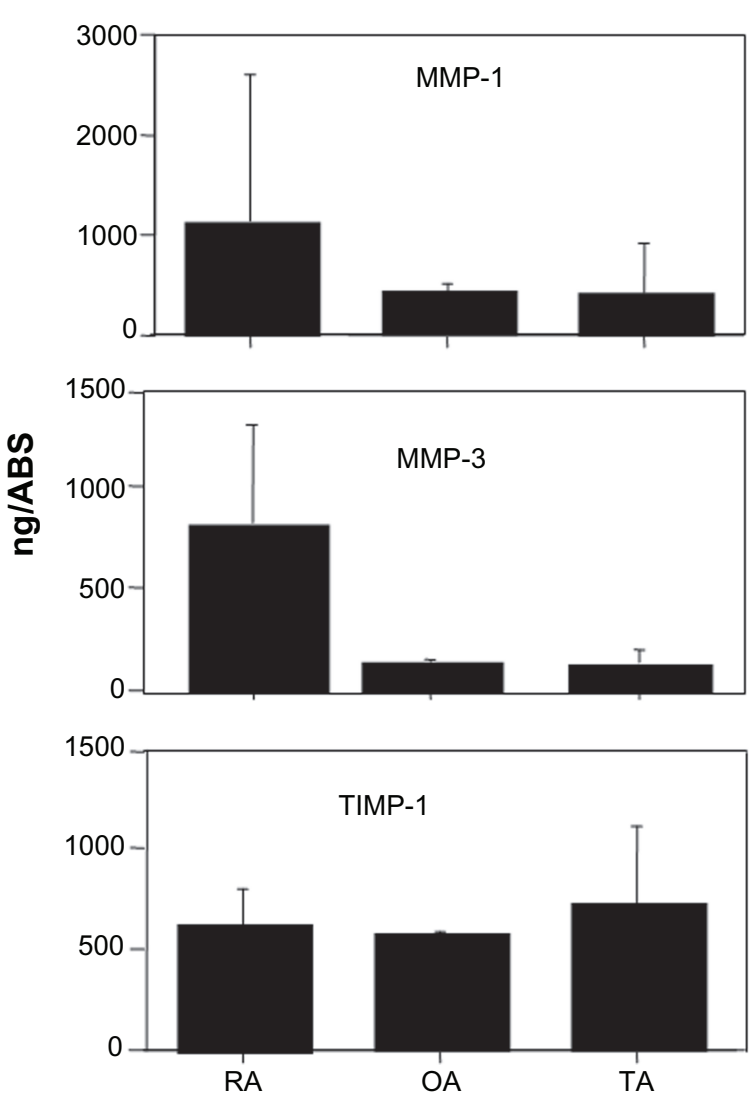
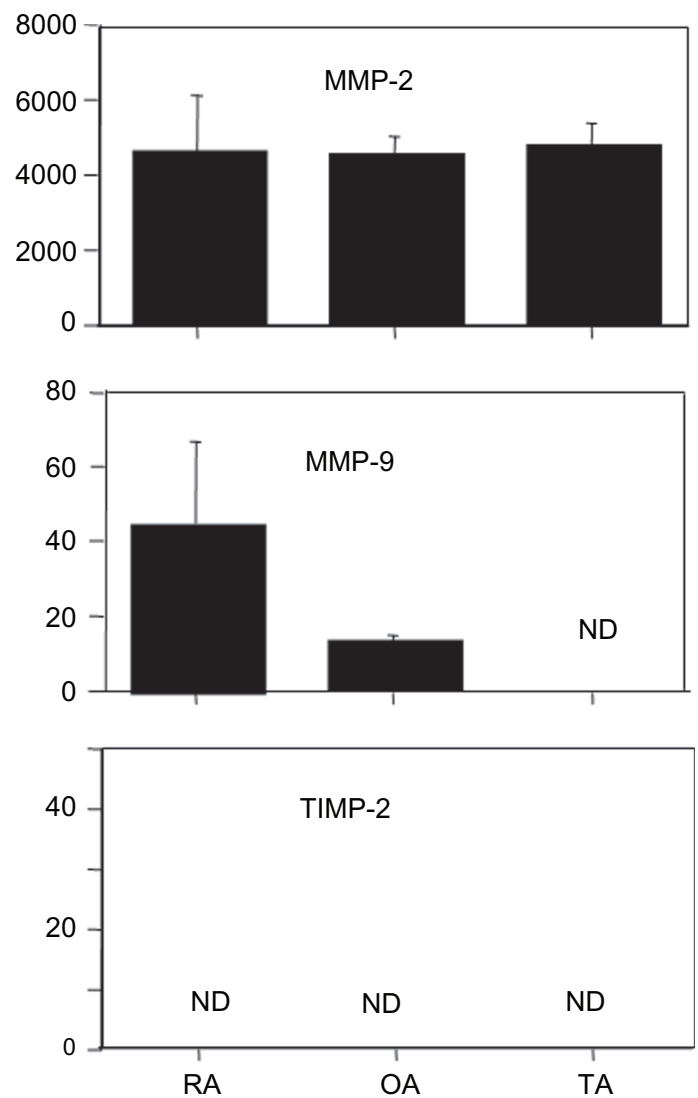

Figure 3 Production of MMPs and TIMPs by untreated synoviocytes obtained from the RA, OA, and TA patients. The amounts of MMP-2 and TIMP-I produced by untreated synoviocytes obtained from the RA, OA, and TA patients did not differ significantly. TIMP-2 level was below the detection limit in all the cells. The synoviocytes obtained from the RA patients tended to produce more MMP-I, MMP-3, and MMP-9 than those obtained from the OA or TA patients.

Abbreviations: RA, rheumatoid arthritis; OA, osteoarthritis; TA, traumatic knee; MMP, matrix metalloproteinase; TIMP, tissue inhibitor of metalloproteinase; ND, undetectable.

\section{Observations in TA patients}

The level of MMP-9 production in the untreated TA synoviocytes was below the detection limit level; therefore, the concentration of MMP-9 produced by TA synoviocytes, when treated, remained below the detection limit, regardless of the test agent used (Figure 3). Treatment with Zn-HA tended to inhibit MMP-2 production in a concentration-dependent manner $(P<0.05)$. Although the synoviocytes produced MMP-3 at detectable levels following treatment with $150 \mu \mathrm{g} / \mathrm{mL} \mathrm{Zn}-\mathrm{HA}$, the concentration of MMP-3 produced was completely blocked after treatment with $200 \mu \mathrm{g} / \mathrm{mL}$ Zn-HA (Figure 4C). Treatment with Zn-HA tended to decrease TIMP-1 production in a concentration-dependent manner (data not shown). The concentration of TIMP-2 produced remained below the detection limit, regardless of the test agent used (data not shown).

\section{Effect of Zn-HA on MMP-9 enzyme} in synoviocytes obtained from RA patients We determined the MMP-9 enzyme in RA synoviocytes by performing gelatin zymography. The zymography experiments revealed that as compared to the MMP-9 activity in the control medium supplemented with PMA ( $100 \mathrm{ng} / \mathrm{mL}$ ), the PMA-induced MMP-9 activity in synoviocytes obtained from RA patients was suppressed by treatment with both $\mathrm{Zn}-\mathrm{HA}$ and $\mathrm{ZnCl}_{2}$ in a dose-dependent manner. $\mathrm{Zn}-\mathrm{HA}(100 \mu \mathrm{g} / \mathrm{mL})$ and $\mathrm{ZnCl}_{2}(10 \mu \mathrm{g} / \mathrm{mL})$ suppressed $60 \%(P<0.05)$ and $40 \%$ of the MMP-9, respectively. Although treatment with $100 \mu \mathrm{g} / \mathrm{mL}$ Na-HA suppressed the MMP-9, the level of suppression was not statistically significant (Figure 5A).

\section{Effect of Zn-HA on MMP-9 mRNA expression in synoviocytes obtained from RA patients}

As compared to the level of MMP-9 mRNA expression in the synoviocytes not treated with PMA [PMA (-)] control, that of MMP-9 mRNA expression was fivefold higher in RA synoviocytes stimulated with PMA [PMA (+)]. However, MMP-9 mRNA expression was suppressed in a dose-dependent manner by treatment with $\mathrm{Zn}-\mathrm{HA}$ and $\mathrm{ZnCl}_{2}$ 

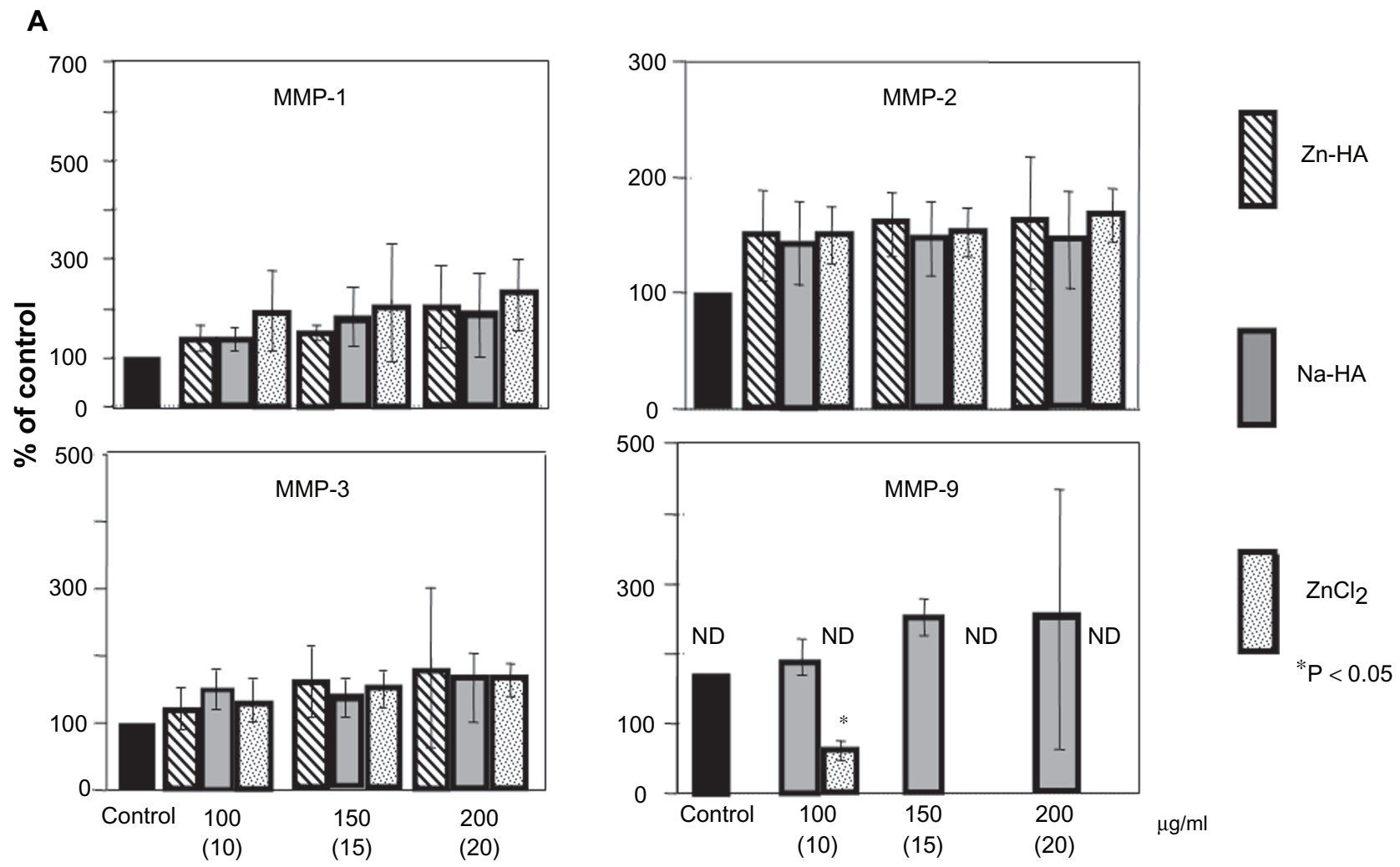

$\mathrm{Zn}-\mathrm{HA} \mathrm{Na}-\mathrm{HA}\left(\mathrm{ZnCl}_{2}\right)$ concentration
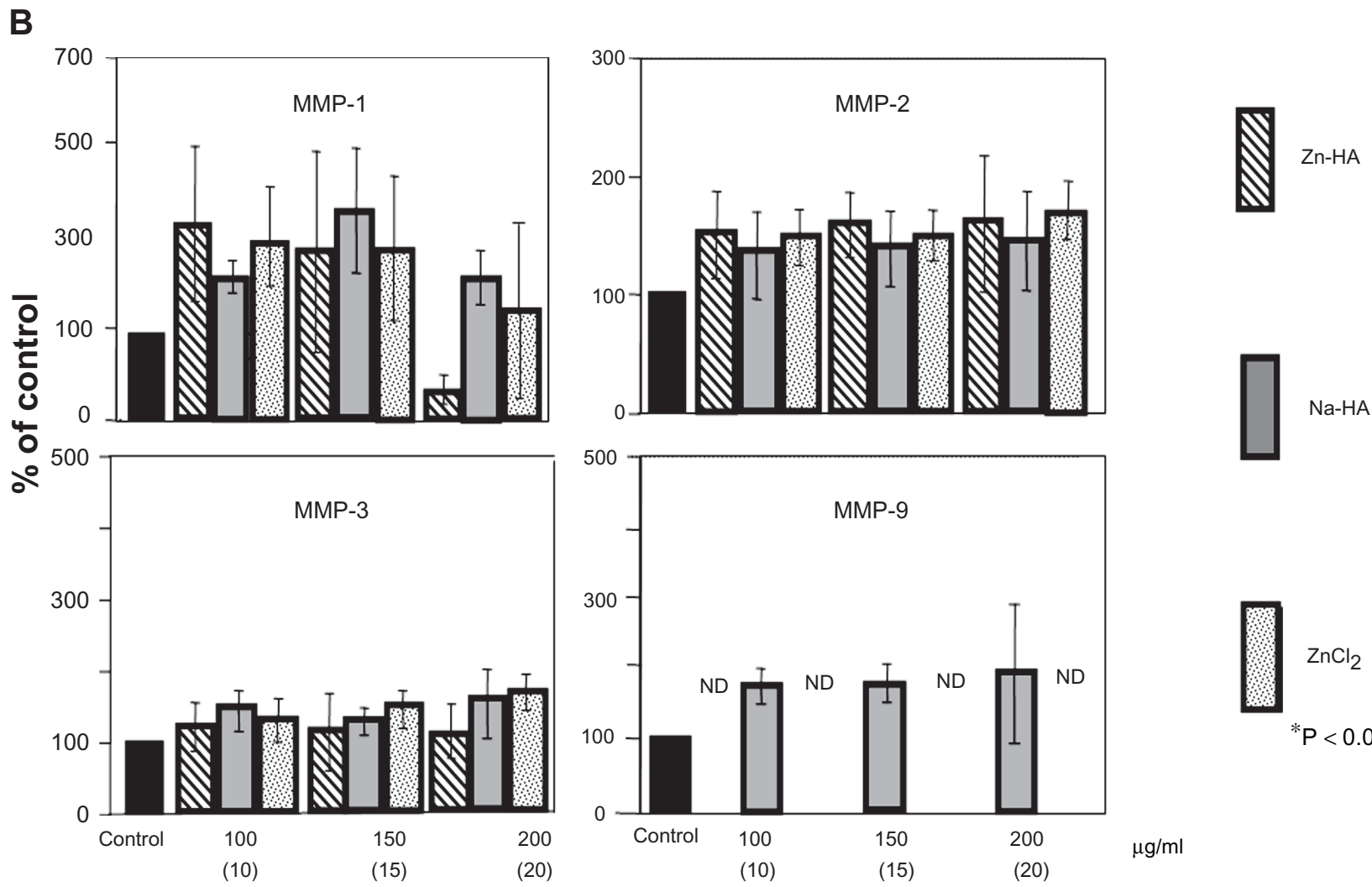

$\mathrm{Zn}-\mathrm{HA}, \mathrm{Na}-\mathrm{HA}\left(\mathrm{ZnCl}_{2}\right)$ concentration 
C

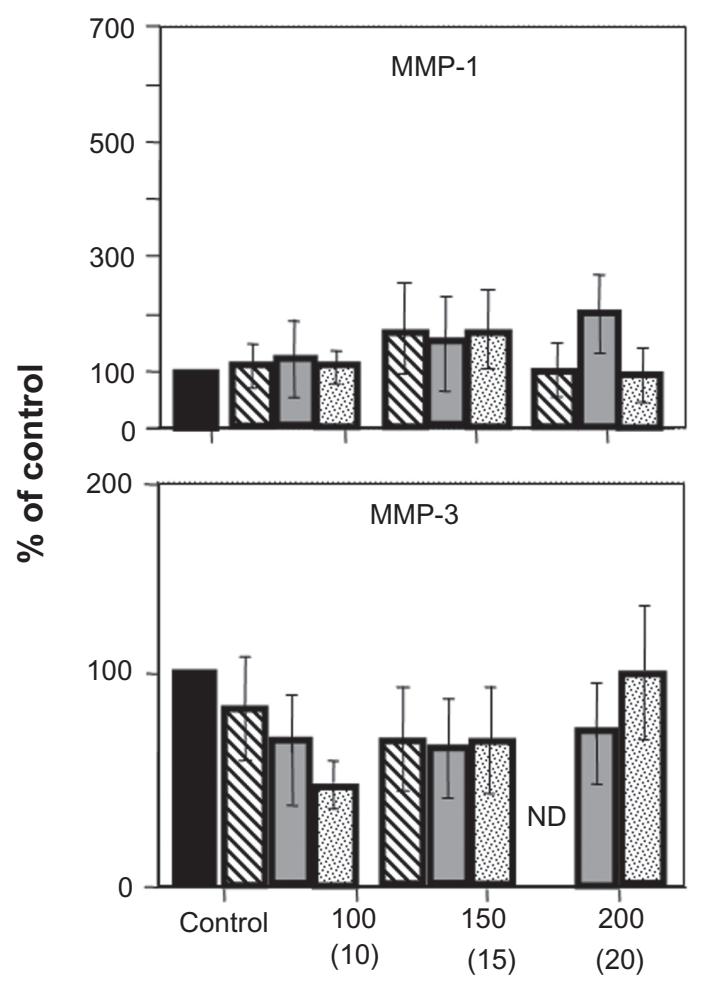

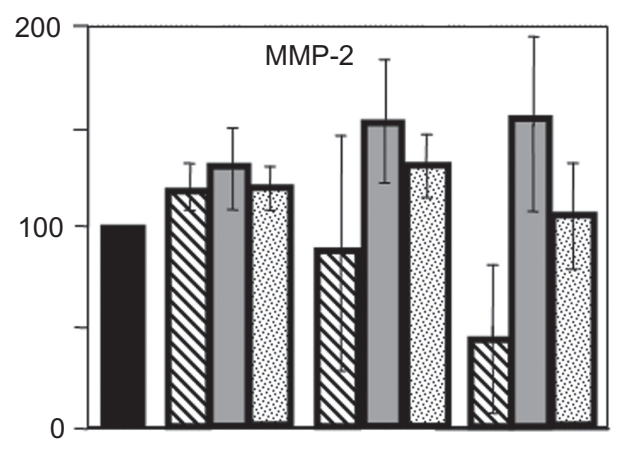

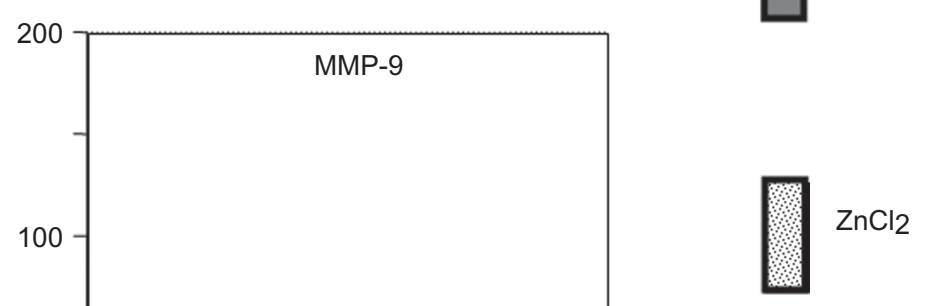

Nn-HA

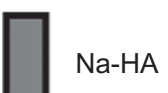

Na-HA

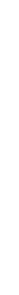

$\mathrm{Zn}-\mathrm{HA}, \mathrm{Na}-\mathrm{HA}\left(\mathrm{ZnCl}_{2}\right)$ concentration

Figure 4 Examination of culture supernatants to determine the effects of $\mathrm{Zn}-\mathrm{HA}$ and other test agents on MMP production in the synoviocytes obtained from the RA A), OA B), and TA C) patients after incubation for eight days. (data not shown for TIMP).

Abbreviations: RA, rheumatoid arthritis; OA, osteoarthritis; TA, traumatic knee; MMP, matrix metalloproteinase; TIMP, tissue inhibitor of metalloproteinase; Zn-HA, zinc hyaluronate; $\mathrm{Na}-\mathrm{HA}$, sodium hyaluronate; $\mathrm{ND}$, undetectable.

in RA synoviocytes stimulated with PMA for $48 \mathrm{~h}$. The Na-HA-treated cells exhibited an overall weak suppression of the MMP-9 mRNA expression. Zn-HA at concentrations of 10,100 , and $200 \mu \mathrm{g}$, and $\mathrm{ZnCl}_{2}$ at concentrations of 10 and $20 \mu \mathrm{g}$ significantly suppressed MMP-9 mRNA expression levels $(P<0.05)$ (Figure 5B).

\section{Effect of $\mathrm{Zn}-\mathrm{HA}$ on apoptosis} in synoviocytes obtained from RA patients $\mathrm{Zn}-\mathrm{HA}$ or Na-HA (at concentrations of 0, 50, 100, and $200 \mu \mathrm{g} / \mathrm{mL}$ ), or $\mathrm{ZnCl}_{2}$ (at concentrations of $0,5,10$, and $20 \mu \mathrm{g} / \mathrm{mL}$ ) was added to the culture medium containing synoviocytes obtained from RA patients. The media were incubated for five days, following which apoptosis was assessed by using either the TUNEL method (Figure 6A) or an ELISA for apoptosis (Figure 6B). Unlike the cells incubated with $200 \mu \mathrm{g} / \mathrm{mL} \mathrm{Na-HA}$, those incubated with $200 \mu \mathrm{g} / \mathrm{mL} \mathrm{Zn-HA}$ or $20 \mu \mathrm{g} / \mathrm{mL} \mathrm{ZnCl}_{2}$ were intensely stained in the TUNEL assay. The apoptosis ELISA revealed that as compared to the treatment with Na-HA, treatment with 100 and $200 \mu \mathrm{g} / \mathrm{mL} \mathrm{Zn}-\mathrm{HA}$ or 10 and $20 \mu \mathrm{g} / \mathrm{mL}$ $\mathrm{ZnCl}_{2}$ significantly induced apoptosis in RA synoviocytes $(P<0.05)$.

\section{Discussion}

Both MMP-9 (92 kDa) and MMP-2 (gelatinase A; 72 kDa) can degrade collagens I, III, IV, and XI as well as aggrecan and link proteins that are mainly found in the cartilage. ${ }^{20}$ Most cell types constitutively express MMP-2, which is not usually induced by cytokines or growth factors. In contrast, basal nonactivated levels of MMP-9 are low; the expression of MMP-9 can be induced by different cytokines/chemokines, including TNF, and it is mainly secreted by inflammatory cells. ${ }^{21}$ MMP-9 levels are obviously elevated in the sera and fluids of RA patients, and they positively correlate with disease progression and severity. ${ }^{22}$ The severity of antibodyinduced arthritis is reduced in MMP-9 knockout mice but exacerbated in MMP-2 knockout mice, indicating that 


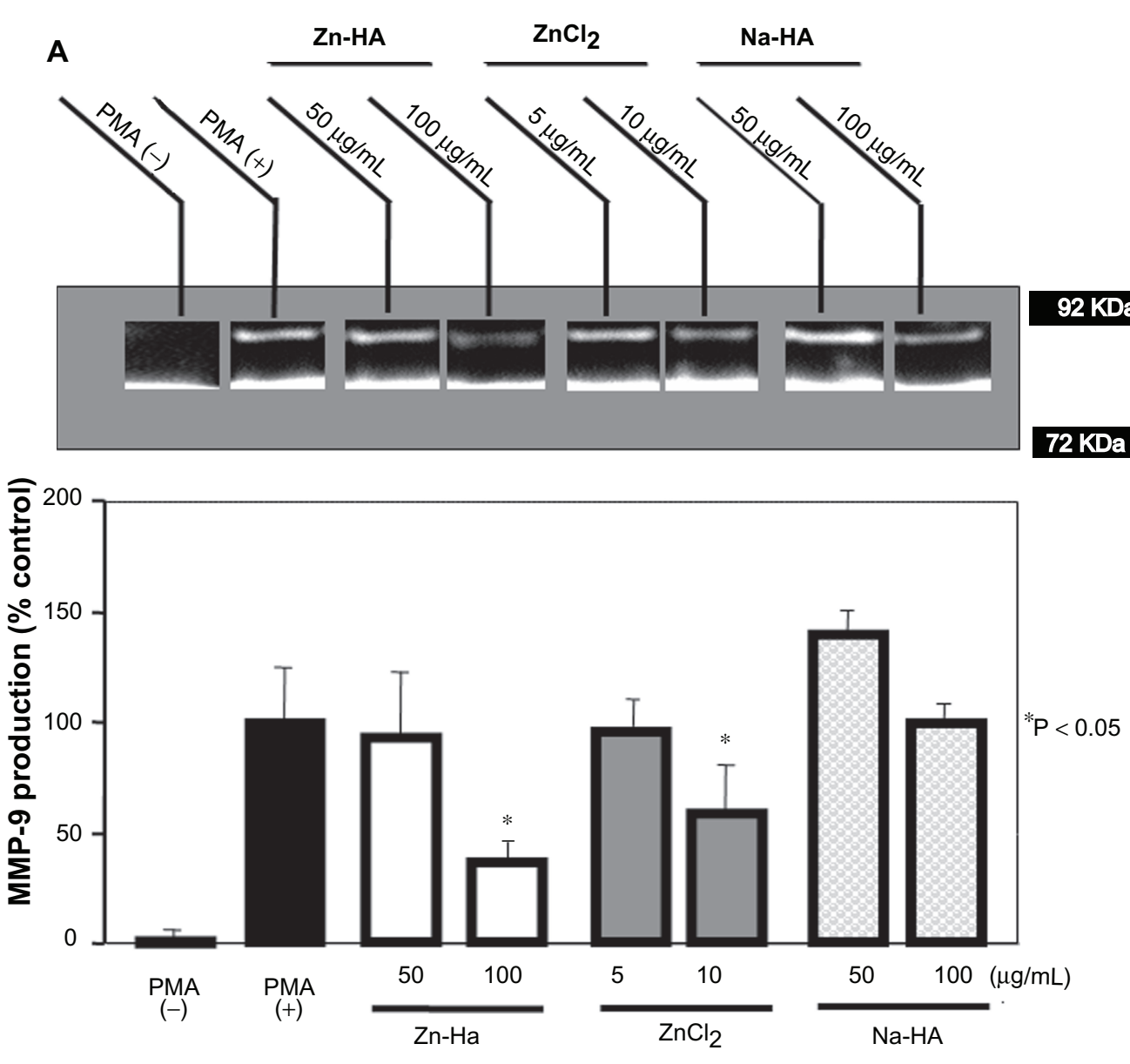

B
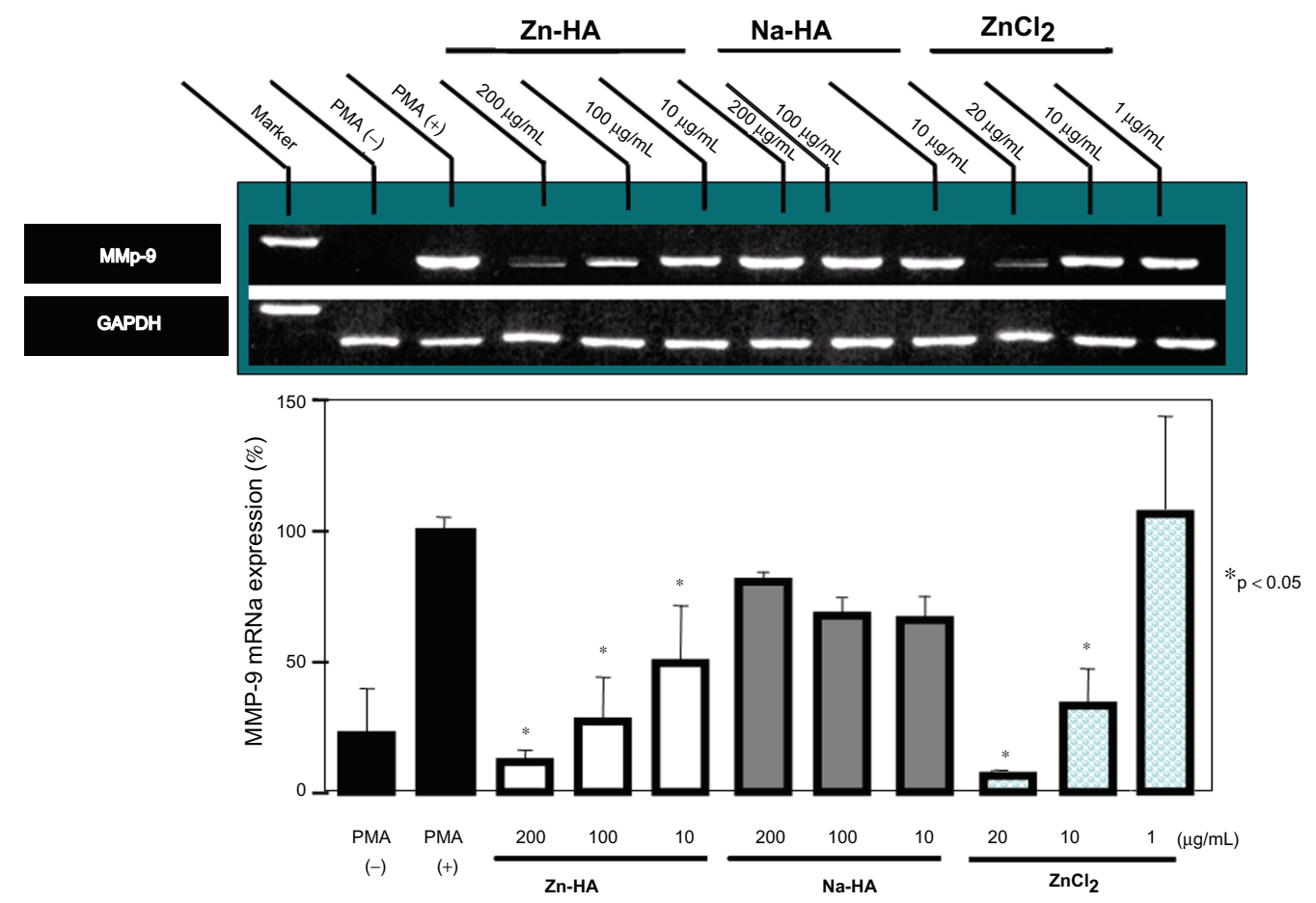

Figure 5 A) Effect of $\mathrm{Zn}-\mathrm{HA}$ on the enzyme of MMP-9 $(92 \mathrm{kDa})$, as determined by gelatin zymography. $\mathrm{MMP}^{-9}$ was dose-dependently suppressed by $\mathrm{Zn}-\mathrm{HA}$ and $\mathrm{ZnCl}{ }_{2}$ but not by Na-HA. MMP-2 (72 kDa) activity was not affected by $\mathrm{Zn}-\mathrm{HA}, \mathrm{ZnCl}_{2}$, or Na-HA. B) Effect of Zn-HA on MMP-9 mRNA expression.

Abbreviations: RA, rheumatoid arthritis; MMP-9, matrix metalloproteinase-9; Zn-HA, zinc hyaluronate; Na-HA, sodium hyaluronate; PMA, phorbol I2-myristate I3-acetate; PMA (-), without PMA; PMA (+), with PMA (I00 ng/mL); Control (-), control without 92-kDa (MMP-9); Control (+), control with 92-kDa (MMP-9). 
A
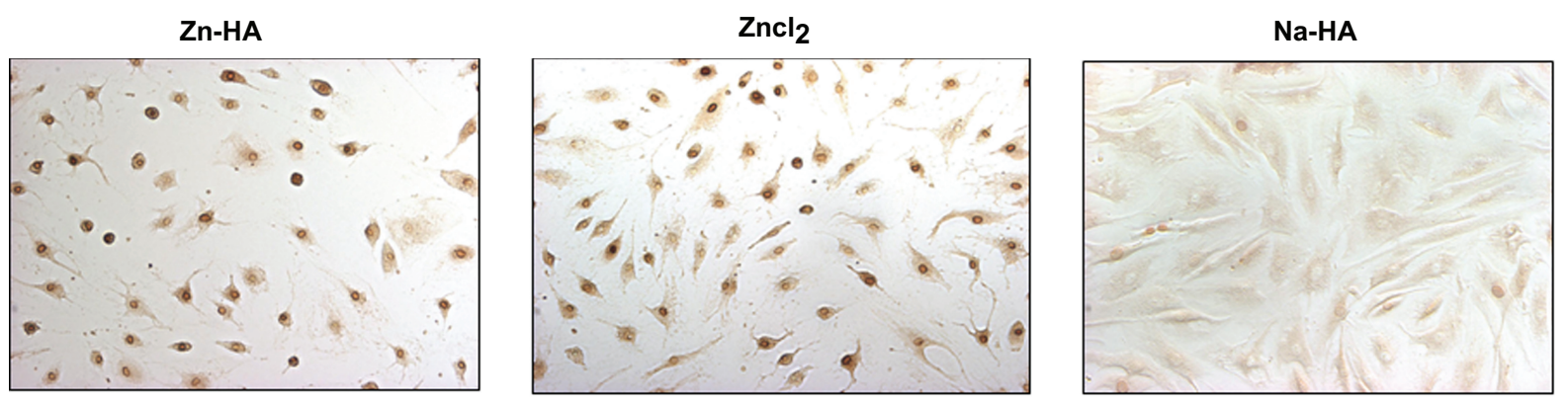

B
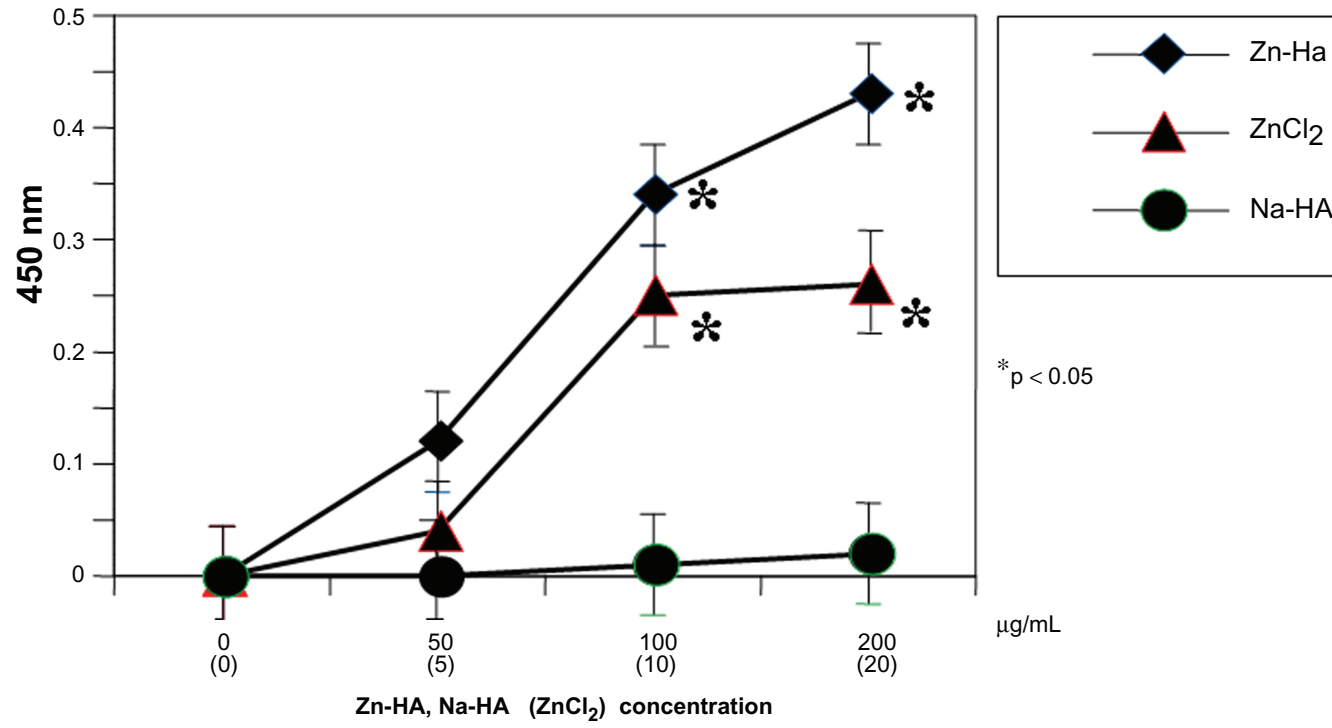

$\longrightarrow$ Na-HA

Figure 6 A) TUNEL assay revealed that $\mathrm{Zn}-\mathrm{HA}(200 \mu \mathrm{g} / \mathrm{mL})$ or $\mathrm{ZnCl}_{2}(20 \mu \mathrm{g} / \mathrm{mL})$, but not Na-HA (200 $\left.\mu \mathrm{g} / \mathrm{mL}\right)$, induced apoptosis in the synoviocytes. B) Apoptosis ELISA assay revealed that $\mathrm{Zn}-\mathrm{HA}$ (dose-dependently) and $\mathrm{ZnCl}_{2}$ induced apoptosis in the synoviocytes, while Na-HA did not.

Abbreviations: Zn-HA, zinc hyaluronate; Na-HA, sodium hyaluronate; TUNEL, terminal deoxynucleotidyl transferase (TdT)-mediated dUTP-biotin nick end labeling.

MMP-2 helps suppress the progression of arthritis. ${ }^{23}$ Thus, MMP-9 expression indicates simultaneous activation of the rheumatoid synovial lining, and MMP-9 positivity indicates that synoviocytes are in an activated state. ${ }^{24,25}$

Among the test agents used in our study, Zn-HA strongly suppressed MMP-9 production, suggesting that Zn-HA exerts an anti-inflammatory effect. De Souza et al reported that $\mathrm{ZnSO}_{4}$ potentially suppresses the production of gingival gelatinases (eg, MMP-9). ${ }^{26}$ In addition, Santos and colleagues found that $\mathrm{ZnO}_{2}$ suppresses the production of MMP-9. ${ }^{27,28}$ These reports, together with the results of our present study, suggest that $\mathrm{Zn}$ in $\mathrm{Zn}$-HA partially suppresses MMP-9 production. Since the effect of Zn-HA is greater than that of $\mathrm{ZnCl}_{2}$ alone, the MMP-9 inhibitory effect of $\mathrm{Zn}-\mathrm{HA}$ is additive as compared to that of $\mathrm{Zn}$ alone. Balogh and colleagues also showed that the synergic effect of $\mathrm{Zn}$ and HA is assumed to be due to the linkage within the Zn-HA complex. ${ }^{6}$ As described above, Zn-HA potentially suppresses MMP-9 production. Therefore, Zn-HA not only exerts an anti-inflammatory effect but may also suppress bone and cartilage destruction by inhibiting MMP-9 production, thereby aiding the maintenance of the osteocartilaginous matrix. During preliminary analysis, we examined aggrecan metabolism following injection of $\mathrm{Zn}-\mathrm{HA}$ into the joints of healthy pigs. The results showed that compared to the saline controls, Zn-HA did not suppress aggrecan synthesis; further, it did not influence the anabolic synthesis of proteoglycan in cartilage (data not shown).

Although other researchers have reported that $\mathrm{Na}-\mathrm{HA}$ sufficiently suppresses synoviocyte proliferation, ${ }^{29}$ we found that $\mathrm{Zn}-\mathrm{HA}$ is more effective than $\mathrm{Na}-\mathrm{HA}$ in inhibiting synoviocyte proliferation. Our findings suggest that $\mathrm{Zn}$ in $\mathrm{Zn}-\mathrm{HA}$ is responsible for this effect; however, $\mathrm{ZnCl}_{2}$ alone was found to be less effective. Although the exact mechanisms of pharmacological action of Zn-HA were not well clarified, another possible explanation for synovial growth inhibition is the biological effect of HA in Zn-HA that is exerted via signal transduction through several hyaluronan receptors such as CD44 and the receptor for hyaluronanmediated motility (RHAMM). ${ }^{30,31}$ 
The exact mechanism underlying the hyperplastic growth of synoviocytes in RA patients remains to be determined; however, these cells are known to play a critical role in joint destruction and undergo expansion, possibly through increased proliferation and/or insufficient apoptosis. Furthermore, disrupted apoptosis may be one of the causes for the hyperplastic growth of synoviocytes in RA patients. Recent investigations have proved that synoviocytes obtained from RA patients resist apoptosis. ${ }^{32}$ Although Na-HA could inhibit FAS or IL-1 beta-induced chondrocyte apoptosis, ${ }^{33,34}$ Fas-induced early apoptosis in the RA synovial cells was augmented by fragmented low-molecular-weight Na-HA, but not by high-molecular-weight Na-HA. ${ }^{35}$ These results at least suggest that Na-HA appears to be unsuccessful in inducing apoptosis in the synovial cells.

Therefore, the treatment strategy would be to design drugs that suppress proliferation and restore normal apoptotic pathways in hyperproliferative cells. Zn-HA appears to effectively suppress the proliferation of synoviocytes in RA patients by inducing apoptosis. In addition to its anti-inflammatory action, Zn-HA may also suppress bone and cartilage destruction by inhibiting the proliferation of fibroblast-like synoviocytes, thereby aiding the maintenance of the osteocartilaginous matrix. Thus, Zn-HA may be very effective as an intra-articular injection therapy for patients with excessive inflammation.

In conclusion, the present study showed that Zn-HA effectively suppressed synoviocyte proliferation via apoptosis induction and inhibited the production of MMP-9. Therefore, we postulate that $\mathrm{Zn}$-HA will be an effective pharmacological agent for the suppression of synovitis and for healing the joint damage caused by effusions.

\section{Acknowledgments}

The authors declare no conflict of interest. Dr Saito had full access to all the data in the study and takes responsibility for the integrity of the data and the accuracy of the data analysis. The study design was performed by Drs Saito and Maekawa. Data was acquired, analyzed and interpreted by Drs Saito, Maekawa, and Kotake. Dr Saito prepared the manuscript. Dr Kotake performed the statistical analysis. Drs Saito and Maekawa selected the patients.

\section{References}

1. Bellamy N, Campbell J, Robinson V, Gee T, Bourne R, Well G. Viscosupplementation for the treatment of osteoarthritis of the knee. Cochrane Database Syst Rev. 2005;2:CD005321.

2. Butler DM, Vitti GF, Leizer T, Hamilton JA. Stimulation of the hyaluronic acid levels of human synovial fibroblasts by recombinant human tumor necrosis factor $\alpha$, tumor necrosis factor $\beta$ (lymphotoxin), interleukin-1 alpha, and interleukin-1ß. Arthritis Rheum. 1988;31(10):1281-1289.
3. Tchetverikov I, Ronday HK, Van El B, et al. MMP profile in paired serum and synovial fluid samples of patients with rheumatoid arthritis. Ann Rheum Dis. 2004;63(7):881-883.

4. Goldbach-Mansky R, Lee JM, Hoxworth JM, et al. Active synovial matrix metalloproteinase- 2 is associated with radiographic erosions in patients with early synovitis. Arthritis Res. 2000;2(2):145-153.

5. Zwerina J, Redlich K, Polzer K, et al. TNF-induced structural joint damage is mediated by IL-1. Proc Natl Acad Sci U S A. 2007;104(28): 11742-11747

6. Balogh GT, Illés J, Székely Z, Forrai E, Gere A. Effect of different metal ions on the oxidative damage and antioxidant capacity of hyaluronic acid. Arch Biochem Biophys. 2003;410(1):76-82.

7. Sakurai K, Andoh M, Yamada M, et al. Suppression of ischemic edema in mice by manganese-hyaluronate conjugate. Jpn J Pharmacol. 1997;74(1):117-120.

8. Barbucci R, Magnani A, Lamponi S, et al. $\mathrm{Cu}$ (II) and $\mathrm{Zn}$ (II) complexes with hyaluronic acid and its sulphated derivative. Effect on the motility of vascular endothelial cells. J Inorg Biochem. 2000;81(4):229-237.

9. Barbucci R, Lamponi S, Magnani A, Piras FM, Rossi A, Weber E. Role of the Hyal-Cu (II) complex on bovine aortic and lymphatic endothelial cells behavior on microstructured surfaces. Biomacromolecules. 2005;68(1):212-219.

10. Burger K, Illés J, Gyurcsik B, et al. Metal ion coordination of macromolecular bioligands: formation of zinc(II) complex of hyaluronic acid. Carbohydr Res. 2001;332(2):197-207.

11. Tratar Pirc E, Zidar J, Bukovec P, Hodoscek M. Molecular modeling of cobalt(II) hyaluronate. Carbohydr Res. 2005;340(12):2064-2069.

12. Van Molle W, Van Roy M, Van Bogaert T, et al. Protection of zinc against tumor necrosis factor induced lethal inflammation depends on heat shock protein 70 and allows safe antitumor therapy. Cancer Res. 2007;67(15):7301-7307.

13. Haase H, Rink L. Signal transduction in monocytes: the role of zinc ions. Biometals. 2007;20(3-4):579-585.

14. Zhou Z, Wang L, Song Z, Saari JT, McClain CJ, Kang YJ. Abrogation of nuclear factor- $\kappa \mathrm{B}$ activation is involved in zinc inhibition of lipopolysaccharide-induced tumor necrosis factor- $\alpha$ production and liver injury. Am J Pathol. 2004;164(5):1547-1556.

15. Goldberg RL, Toole BP. Hyaluronate inhibition of cell proliferation. Arthritis Rheum. 1987;30(7):769-778.

16. Fujii K, Fujii Y, Hubscher S, Tanaka Y. CD44 is the physiological trigger of Fas up-regulation on rheumatoid synovial cells. J Immunol. 2001;167(3):1198-1203.

17. Arnett FC, Edworthy SM, Bloch DA, et al. The American Rheumatism Association 1987 revised criteria for the classification of rheumatoid arthritis. Arthritis Rheum. 1988;31(3):315-324.

18. Altman R, Asch E, Bloch D, et al. Development of criteria for the classification and reporting of osteoarthritis. Classification of osteoarthritis of the knee. Diagnostic and Therapeutic Criteria Committee of the American Rheumatism Association. Arthritis Rheum. 1986;29(8):1039-1049.

19. Mosmann T. Rapid colorimetric assay for cellular growth and survival: application to proliferation and cytotoxicity assays. J Immunol Methods. 1983;65(1-2):55-63.

20. Nguyen Q, Murphy G, Hughes CE, Mort JS, Roughley PJ. Matrix metalloproteinases cleave at two distinct sites on human cartilage link protein. Biochem J. 1993;295(Pt 2):595-598.

21. Ahrens D, Koch AE, Pope RM, Stein-Picarella M, Niedbala MJ. Expression of matrix metalloproteinase 9 (96-kd gelatinase B) in human rheumatoid arthritis. Arthritis Rheum. 1996;39(9):1576-1587.

22. Gruber BL, Sorbi D, French DL, et al. Markedly elevated serum MMP-9 (gelatinase B) levels in rheumatoid arthritis: a potentially useful laboratory marker. Clin Immunol Immunopathol. 1996;78(2):161-171.

23. Itoh T, Matsuda H, Tanioka M, Kuwabara K, Itohara S, Suzuki R. The role of matrix metalloproteinase-2 and matrix metalloproteinase-9 in antibody-induced arthritis. J Immunol. 2002;169(5):2643-2647.

24. Tchetverikov I, Lard LR, DeGroot J, et al. Matrix metalloproteinases-3, $-8,-9$ as markers of disease activity and joint damage progression in early rheumatoid arthritis. Ann Rheum Dis. 2003;62(11):1094-1099. 
25. Chia WT, Chen YW, Cheng LY, Lee HS, Chang DM, Sytwu HK. MMP-9 mRNA as a therapeutic marker in acute and chronic stages of arthritis induced by type II collagen antibody. J Formos Med Assoc. 2008;107(3):245-252.

26. de Souza AP, Gerlach RF, Line SR. Inhibition of human gingival gelatinases (MMP-2 and MMP-9) by metal salts. Dent Mater. 2000; 16(2):103-108.

27. Santos MC, de Souza AP, Gerlach RF, Trevilatto PC, Scarel-Caminaga RM, Line SR. Inhibition of human pulpal gelatinases (MMP-2 and MMP-9) by zinc oxide cements. J Oral Rehabil. 2004;31(7):660-664.

28. Santos MC, Souza AP, Gerlach RF, Tabchoury CM, Line SR. Inhibition of human gelatinases (matrix metalloproteinase-2 and matrix metalloproteinase-9) activity by zinc oxide: a possible mechanism to enhance wound healing. Br J Dermatol. 2001;145(5):854-855.

29. Takahashi K, Goomer RS, Harwood F, Kubo T, Hirasawa Y, Amiel D. The effects of hyaluronan on matrix metalloproteinase-3 (MMP-3), interleukin-1 $\beta$ (IL-1 $\beta$ ), and tissue inhibitor of metalloproteinase-1 (TIMP-1) gene expression during the development of osteoarthritis Osteoarthritis Cartilage. 1999;7(2):182-190.
30. Naor D, Nedvetzki S. CD44 in rheumatoid arthritis. Arthritis Res Ther 2003;583:105-115.

31. Yadav AK, Mishra P, Agrawal GP. An insight on hyaluronic acid in drug targeting and drug delivery. J Drug Target. 2008;16(2):91-107.

32. Pope RM. Apoptosis as a therapeutic tool in rheumatoid arthritis. Nat Rev Immunol. 2002;2(7):527-535.

33. Lisignoli G, Grassi F, Zini N, et al. Anti-Fas-induced apoptosis in chondrocytes reduced by hyaluronan: evidence for CD44 and CD54 (intercellular adhesion molecule 1) involvement. Arthritis Rheum. 2001; 44(8):1800-1807.

34. Zhou PH, Liu SQ, Peng H. The effect of hyaluronic acid on IL-1betainduced chondrocyte apoptosis in a rat model of osteoarthritis. J Orthop Res. 2008;26(12):1643-1648.

35. Fujii K, Fujii Y, Hubscher S, Tanaka Y. CD44 is the physiological trigger of Fas up-regulation on rheumatoid synovial cells. J Immunol. 2001;167(3):1198-1203.

\section{Publish your work in this journal}

The Journal of Inflammation Research is an international, peer-reviewed open-access journal that welcomes laboratory and clinical findings on the molecular basis, cell biology and pharmacology of inflammation including original research, reviews, symposium reports, hypothesis formation and commentaries on: acute/chronic inflammation; mediators of inflamma-

\section{Dovepress}

tion; cellular processes; molecular mechanisms; pharmacology and novel anti-inflammatory drugs; clinical conditions involving inflammation. The manuscript management system is completely online and includes a very quick and fair peer-review system. Visit http://www.dovepress.com/ testimonials.php to read real quotes from published authors.

Submit your manuscript here: http://www.dovepress.com/journal-of-inflammation-research-journal 